\title{
Swimming performance and metabolic rate of flatback Natator depressus and loggerhead Caretta caretta sea turtle hatchlings during the swimming frenzy
}

\author{
Carla M. Pereira ${ }^{1, *}$, David T. Booth ${ }^{1}$, Colin J. Limpus ${ }^{2}$ \\ ${ }^{1}$ The University of Queensland, Physiological Ecology Group, School of Biological Sciences, Queensland 4072, Australia \\ ${ }^{2}$ Department of Environment and Resource Management, PO Box 2454, Brisbane, Queensland 4001, Australia
}

\begin{abstract}
Swimming performance influences the dispersal success of sea turtle hatchlings when they first enter the water and engage in a 'swimming frenzy' which moves them rapidly offshore. We simultaneously measured swim thrust (in millinewtons, $\mathrm{mN}$ ) and metabolic rate (in milliwatts, mW) of loggerhead Caretta caretta and flatback turtle Natator depressus hatchlings during the first $18 \mathrm{~h}$ of the swimming frenzy and compared the results with previous data from green turtle Chelonia mydas hatchlings. Metabolic rate was correlated with swim thrust in all species. In all species, swim thrust decreased sharply during the first $2 \mathrm{~h}$ of swimming, continued to slowly decrease until $12 \mathrm{~h}$ and remained constant at this lowest level until experiments ended at $18 \mathrm{~h}$. Metabolic rate had a similar pattern, with a steep drop during the first $2 \mathrm{~h}$ followed by a less steep decrease before becoming relatively constant. Swim thrust and metabolic rate were highest in green turtle hatchlings. Flatback hatchling metabolic rate was similar to green turtle hatchlings but they weighed almost twice as much, while loggerhead hatchlings had the lowest metabolic rate. Flatback hatchling swim thrust decreased the fastest, falling below that of green turtle hatchlings within the first hour of swimming and falling below loggerhead turtle hatchlings after $12 \mathrm{~h}$ of swimming. These findings suggest that flatback hatchlings have a different dispersal behaviour compared to green and loggerhead hatchlings. The shorter highly vigorous swimming period of flatback turtles might be explained by the fact that they do not swim into off-shore oceanic dispersing currents, and managing their energy resources might be a strategic adaptation to survive predators in a relatively constant environment.
\end{abstract}

KEY WORDS: Swimming frenzy $\cdot$ Metabolic rate $\cdot$ Thrust $\cdot$ Hatchling $\cdot$ Sea turtle $\cdot$ Predator Resale or republication not permitted without written consent of the publisher

\section{INTRODUCTION}

After emerging from nests, sea turtle hatchlings crawl to the sea and typically enter a 'swimming frenzy' which quickly moves them into offshore oceanic currents (Salmon \& Wyneken 1987, Wyneken \& Salmon 1992, Hays et al. 2010). During the swimming frenzy, hatchlings swim continuously for approximately $24 \mathrm{~h}$ (Salmon et al. 2009), living solely on their yolk reserves (Wyneken \& Salmon 1992, Wyneken 1997). Typically, swimming shifts from using a primarily 'powerstroking' gait in which lift and dragbased foreflipper movement is used to produce thrust, to primarily a 'dogpaddling' gait in which an alternately 4 -flipper movement is used to produce thrust towards the end of the swimming frenzy (Salmon \& Wyneken 1987, Wyneken \& Salmon 1992). During this time, sea turtle hatchlings typically swim within $1 \mathrm{~m}$ of the surface, which not only reduces surface drag (Hays et al. 2001) but also make hatchlings less obvious to aerial predators (Witherington \& Salmon 1992, Hays et al. 2001). Previous studies have demon- 
strated that the fastest powerstroke rates occur early in the swimming frenzy (Salmon \& Wyneken 1987, Wyneken \& Salmon 1992, Burgess et al. 2006, Booth 2009, Ischer et al. 2009) when the rate of oxygen consumption $\left(\mathrm{O}_{2}\right)$ is greatest (Wyneken 1991, Wyneken 1997, Booth 2009). From that point onwards, both powerstroke rate and $\mathrm{O}_{2}$ decrease. Nevertheless, there are intraspecific (Wyneken et al. 2008) and interspecific (Wyneken \& Salmon 1992, Jones et al. 2003, 2007) differences in sea turtle hatchling swimming behaviour. Although green turtle Chelonia mydas (Linnaeus, 1758), loggerhead turtle Caretta caretta (Linnaeus, 1758) and leatherback turtle Dermochelys coriacea (Vandelli 1761) are long-distance migratory species, green hatchlings are reported to have the largest aerobic scope (ratio of $\mathrm{O}_{2}$ at rest to $\mathrm{O}_{2}$ during maximal swimming), loggerhead hatchlings have an intermediate aerobic scope, and leatherback hatchlings have the lowest aerobic scope (Wyneken 1997). During post-frenzy swimming, both the time spent actively swimming and $\mathrm{O}_{2}$ decrease significantly in all 3 species (Wyneken 1997).

It has been hypothesized that sea turtle hatchling swimming behaviour during dispersal off-shore has been molded by selection to minimize predator encounters (the 'predation risk' hypothesis; Chung et al. 2009a,b, Salmon et al. 2009). Predation pressure in the near-shore environment and the distance between the nesting beaches and nearby oceanic currents appear to influence the vigour of the frenzy swim, with hatchlings swimming more vigorously when having to swim farther to reach offshore oceanic currents (Wyneken et al. 2008, Chung et al. 2009a, Putman et al. 2010).

Very little is known about flatback turtle Natator depressus (Garman, 1880) hatchling swimming behaviour (Wyneken 1997, Salmon et al. 2009). Flatback turtle hatchlings are the second largest (Pritchard \& Mortimer 1999) and second heaviest (Miller 1997) among sea turtles. Walker \& Parmenter (1990) hypothesized that flatback turtle hatchlings might have a strong swimming ability because of their large size and presumably larger yolk reserves. If this statement is true, one would expect larger sea turtle hatchlings to generate greater swim thrust. However, comparative studies between loggerhead, green and leatherback hatchlings indicate that the larger leatherback hatchlings are slower swimmers, with slower flipper movements compared to smaller green and loggerhead turtle hatchlings (Wyneken 1997).

Flatback turtles are confined to the Australian continental shelf (Limpus 2008b), and hatchlings are thought not to disperse into mid-ocean currents
(Wyneken 1997). For this reason, it has been speculated that this species has an abbreviated swimming frenzy (Wyneken 1997), and, if so, this phase might be less intense when compared to green and loggerhead turtles that migrate to the mid-ocean. However, a recent laboratory study reported that flatback turtle hatchlings swim more or less continuously for several days after entering the water (Salmon et al. 2009), but there is no record of how vigorously they swim during this time. Hence, in this study, we tested the hypothesis that swimming behaviour and the energetics of swimming differ among species of hatchling seas turtles by measuring swimming performance (quantified by swim thrust) and metabolic rate during the first $18 \mathrm{~h}$ of the swimming frenzy. We also interpret patterns of swimming effort and metabolic rate in light of what is known about the dispersal strategy of these species.

\section{MATERIALS AND METHODS}

\section{Study site}

This study was conducted at Mon Repos Conservation Park ( $\left.24^{\circ} 48^{\prime} \mathrm{S}, 152^{\circ} 27^{\prime} \mathrm{E}\right)$, Queensland, the biggest and best monitored turtle rookery on the east coast of the Australian mainland (Pfaller 2008). Several hundred loggerheads and about 10 flatbacks nest at this site each year, and all females are tagged (Limpus et al. 1984, Limpus \& Limpus 2003, Limpus 2008a,b).

\section{Evaluation of aerobic swimming performance}

Swim thrust and metabolic rate were measured in newly emerged loggerhead and flatback turtle hatchlings between 5 January and 11 February 2010. Nests were monitored for emergence throughout the night, and when an emergence event occurred, a single hatchling from a nest was randomly selected and transported dry in a bucket to the laboratory, a process that took between 10 and $15 \mathrm{~min}$. During this transport time, hatchlings crawled around inside the bucket, a behaviour similar to a wild hatchling crawling down the beach towards the sea.

All hatchlings were weighed to $0.1 \mathrm{~g}$ on an electronic balance (AND Model EK-1200A), and straight carapace length (SCL), straight carapace width (SCW), body thickness (BT) and right front flipper total length (RFFTL) were measured to $0.1 \mathrm{~mm}$ with a calliper (Kincrome Stainless Hardened S07702) before the swimming trial. Swim thrust (millinewtons, 
$\mathrm{mN}$ ) and metabolic rate (milliwatts, $\mathrm{mW}$ ) were measured simultaneously during the first $18 \mathrm{~h}$ of swimming following the method of Booth (2009). Briefly, hatchlings were placed in a tank $(34 \mathrm{~cm}$ long $\times 28 \mathrm{~cm}$ wide $\times$ $19 \mathrm{~cm}$ high) filled with $16 \mathrm{~cm}$ of $28^{\circ} \mathrm{C}$ water, the average offshore water temperature at Mon Repos (28 \pm $1{ }^{\circ} \mathrm{C}$, Bennett et al. 1986). The tank was painted black except on 1 side, where a low intensity light was placed to induce directional swimming. The tank was sealed with a lid using vacuum grease. Three $2 \mathrm{~mm}$ holes were drilled in the lid, 1 at the front corner to allow continuous air entrance, the second at the back corner diagonally opposite to the air entrance where a tube was attached to sample chamber air at a rate of 90 to $100 \mathrm{ml} \mathrm{min}^{-1}$, and the third in the middle on the lid where a monofilament tether passed through connecting a force transducer (MLT050 ADInstruments) to a lycra harness that was fitted to the hatchling. The force transducer was connected to a bridge amplifier (ML112 ADInstruments) and the output of the bridge amplifier recorded via a data acquisition system (Power Lab 8/20 using LabChart v6.0 software, ADInstruments). The tether's length was adjusted so that the hatchling could swim freely but could not touch the walls or bottom of the tank. Water temperature in the tank was monitored by a thermocouple converter (SMCJ-T Omega.com, Omega Engineering). Air was drawn from the air space above the water, passed through a drierite ${ }^{\circledR}$ water absorber through a massflow meter (FMA 0-100 ml min ${ }^{-1}$ Omega.com, Omega Engineering) and through an oxygen analyser (PA-1B Sable Systems) and a pump before being vented to the atmosphere. The oxygen analyser was calibrated before and after measurements with high purity nitrogen and dried room air. The oxygen analyser had a heated measurement cell with an inbuilt barometric pressure compensator so that small changes in room temperature $\left(24\right.$ to $\left.29^{\circ} \mathrm{C}\right)$ and barometric pressure (101.2 to $101.4 \mathrm{kPa}$ ) did not cause the baseline to shift, and the drift in span was always less than $0.02 \%$ during the measurement period. We assumed a linear drift in the span during this time to make a correction, but this correction was always very small. Likewise, the force transducer was calibrated before and after measurement by suspending a known mass from the force transducer. Signals from the oxygen analyser, flowmeter and thermocouple were sampled every $30 \mathrm{~s}$, and the signal from the force transducer sampled at $40 \mathrm{~Hz}$.

In order to apply an instantaneous correction to metabolic rate (Bartholomew et al. 1981), the washout characteristics of the respirometry system were measured by flushing the system with nitrogen and monitoring the rate at which the oxygen concentra- tion changed when room air was drawn into the system. These data were used to calculate the system's effective volume. Metabolic rate (in mW) was determined by first calculating oxygen consumption using Eq. 11.2 of Lighton (2008) assuming that the ratio of $\mathrm{CO}_{2}$ eliminated per $\mathrm{O}_{2}$ consumed, i.e. respiratory quotient (RQ) was 0.80 after the washout correction was applied to fractional concentration of oxygen in air entering the oxygen analyser $\left(\mathrm{F}_{\mathrm{O} 2} \mathrm{Out}\right)$ :

$$
\dot{\mathrm{V}}_{\mathrm{O} 2}=1.044 \times \mathrm{FR} \times\left(0.2095-\mathrm{F}_{\mathrm{O} 2} \mathrm{Out}\right)
$$

where FR = flow rate of dry air exiting the chamber and $1.044=1 /[1-0.2095 \times(1-0.8)]$.

Oxygen consumption was then converted to watts assuming an RQ of 0.80 and using an oxy-joule equivalent of $20.13 \mathrm{~J} \mathrm{ml}^{-1} \mathrm{O}_{2}$ (Lighton et al. 1987). As pointed out by Koteja (1996), when converting oxygen consumption into energy equivalents for metabolic rate, if one assumes an RQ of 0.8 instead of the actual $R Q$, the error introduced to the calculations is less than $0.6 \%$ over the entire physiological range of RQ because errors caused by an incorrect assumption of $\mathrm{RQ}$ are in opposite directions and essentially cancel each other out. Thrust was calculated in $\mathrm{mN}$ by using the unit conversion facility option in the LabChart v6.0 software (ADInstruments). Mean metabolic rate and thrust were calculated for each individual turtle hatchling every $10 \mathrm{~min}$ interval throughout the entire $18 \mathrm{~h}$ period of swimming.

\section{Statistical analysis}

Data for green turtle hatchlings from a previous study (Booth 2009) were included to enable comparisons across 3 species. Statistical significance was assumed if $p<0.05$. The relationship between swim thrust and metabolic rate in hatchlings was estimated by linear regression analysis. Interspecific differences in hatchlings mass, swim thrust and metabolic rate during the first $10 \mathrm{~min}$ of swimming after entering the water, and swim thrust and metabolic rate during the last $10 \mathrm{~min}$ of the swimming trial (i.e. after $17 \mathrm{~h}$ and $50 \mathrm{~min}$ of swimming) were performed using a 2-way analysis of variance (ANOVA; species and measurement time fixed factors). Further 1-way ANOVA comparisons between hatchlings from the 3 species were performed for SCL, SCW, BT and RFFTL. A crude measure of swimming efficiency (thrust produced per rate of energy use; $\mathrm{N} \mathrm{W}^{-1}$ ) was calculated by dividing the thrust produced by the metabolic rate for each 10 min interval throughout the $18 \mathrm{~h}$ swimming period. 


\section{RESULTS}

In total, 28 hatchlings were sampled: 15 loggerheads and 13 flatbacks. Data from 5 green turtle hatchlings from Heron Island collected by Booth (2009) were also included to allow interspecies comparisons.

\section{Loggerhead hatchlings}

Metabolic rate decreased rapidly from 96 to $50 \mathrm{~mW}$ during the first $2 \mathrm{~h}$ of swimming, followed by a slower decrease from 50 to $35 \mathrm{~mW}$ between 2 and $8 \mathrm{~h}$ (Fig. 1A). From 8 to $18 \mathrm{~h}$, the metabolic rate was rel-

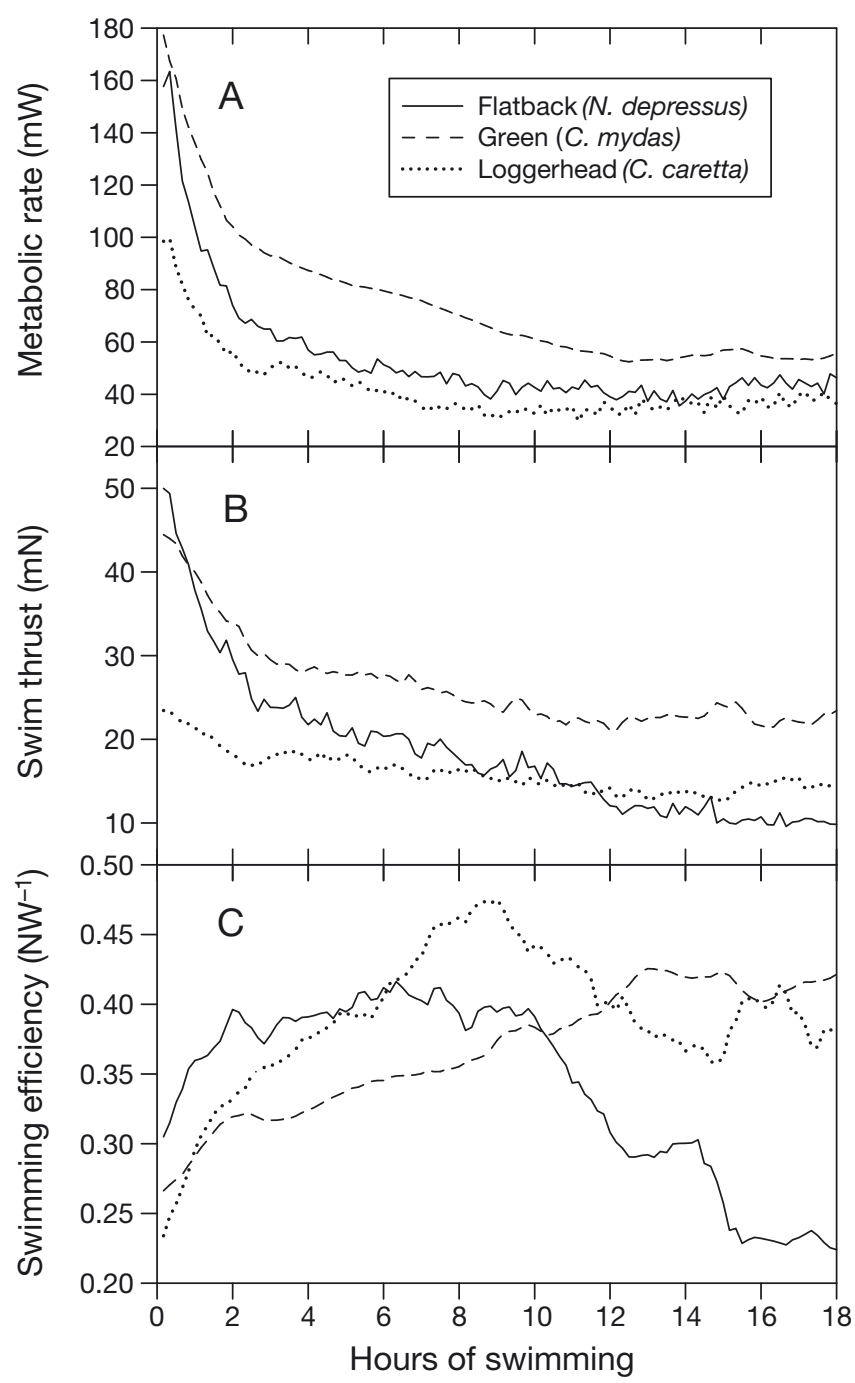

Fig. 1. Natator depressus, Caretta caretta and Chelonia mydas. (A) Metabolic rate, (B) swim thrust and (C) swimming efficiency during the first $18 \mathrm{~h}$ of frenzy swimming in flatback and loggerhead turtle hatchlings from Mon Repos rookery and green turtle hatchlings from Heron Island rookery. Each point corresponds to the 10 min mean of each variable atively constant, averaging $35 \mathrm{~mW}$ (Fig. 1A). Swim thrust followed the metabolic rate pattern, decreasing sharply from 23 to $17 \mathrm{mN}$ within the first $2 \mathrm{~h}$ of swimming, then decreased at a slower rate between 2 and $12 \mathrm{~h}$ of swimming (from 17 to $14 \mathrm{mN}$; Fig. 1B). After $12 \mathrm{~h}$ of swimming, swim thrust remained relatively constant, averaging $14 \mathrm{mN}$ until the trial ended at $18 \mathrm{~h}$ (Fig. 1B). Swimming efficiency increased steadily for the first $8.5 \mathrm{~h}$ of swimming from 0.24 to $0.49 \mathrm{~N} \mathrm{~W}^{-1}$ and then decreased steadily to $0.35 \mathrm{~N} \mathrm{~W}^{-1}$ at $14.5 \mathrm{~h}$ (Fig. 1C). After $14.5 \mathrm{~h}$, swimming efficiency increased to another small peak at $16 \mathrm{~h}$ before decreasing again to $0.35 \mathrm{~N} \mathrm{~W}^{-1}$ after $18 \mathrm{~h}$ (Fig. 1C). Swim thrust was positively correlated with metabolic rate (Fig. 2).

\section{Flatback hatchlings}

In total, 13 hatchlings were sampled, but due to a technical problem, swim thrust and metabolic rate data from 1 hatchling were not recorded for the first $1.2 \mathrm{~h}$. Both the metabolic rate and mean force decreased with increased swim time (Fig. 1A,B). Metabolic rate decreased rapidly from 160 to $73 \mathrm{~mW}$ from 0 to $2 \mathrm{~h}$, then decreased steadily from 73 to $45 \mathrm{~mW}$ during 2 to $6 \mathrm{~h}$ and averaged $45 \mathrm{~mW}$ until the trial ended at $18 \mathrm{~h}$ (Fig. 1A). Swim thrust also decreased rapidly from 48 to $29 \mathrm{mN}$ from 0 to $2 \mathrm{~h}$, then decreased steadily from 29 to $11 \mathrm{mN}$ from 2 to $18 \mathrm{~h}$ (Fig. 1B). Swimming efficiency increased steadily from 0.32 to $0.43 \mathrm{~N} \mathrm{~W}^{-1}$ from 0 to $6.5 \mathrm{~h}$, then decreased slowly to $0.37 \mathrm{~N} \mathrm{~W}^{-1}$ at $10 \mathrm{~h}$ before decreasing sharply to $0.22 \mathrm{~N} \mathrm{~W}^{-1}$ at $15.5 \mathrm{~h}$ where it remained until the trial finished at $18 \mathrm{~h}$ (Fig. 1C). Swim thrust was positively correlated with metabolic rate (Fig. 2).

\section{Green hatchlings}

As reported by Booth (2009), metabolic rate decreased rapidly from 177 to nearly $100 \mathrm{~mW}$ during the first $2 \mathrm{~h}$ of swimming, followed by a slower decrease from 100 to $55 \mathrm{~mW}$ between 2 and $12 \mathrm{~h}$ (Fig. 1A). From 12 to $18 \mathrm{~h}$, the metabolic rate was relatively constant, averaging $55 \mathrm{~mW}$ (Fig. 1A). Swim thrust followed the metabolic rate pattern, decreasing sharply from 45 to $33 \mathrm{mN}$ within the first $2 \mathrm{~h}$ of swimming (Fig. 1B). Between 2 and 12 h, it decreased slowly from 33 to $22 \mathrm{mN}$, and from $12 \mathrm{~h}$ onwards, swim thrust remained constant at $22 \mathrm{mN}$ (Fig. 1B). Swimming efficiency increased steadily for the first $12.5 \mathrm{~h}$ of swimming from 0.25 to $0.43 \mathrm{~N} \mathrm{~W}^{-1}$ and 
remained constant at that level until the end of the trial, with only a slight decrease between 15.5 and $16.5 \mathrm{~h}$ (Fig. 1C). Swim thrust was positively correlated with metabolic rate (Fig. 2).

\section{Comparison among loggerhead, flatback and green turtle hatchlings}

After testing for normality and homoscedasticity, ANOVAs were performed comparing variables

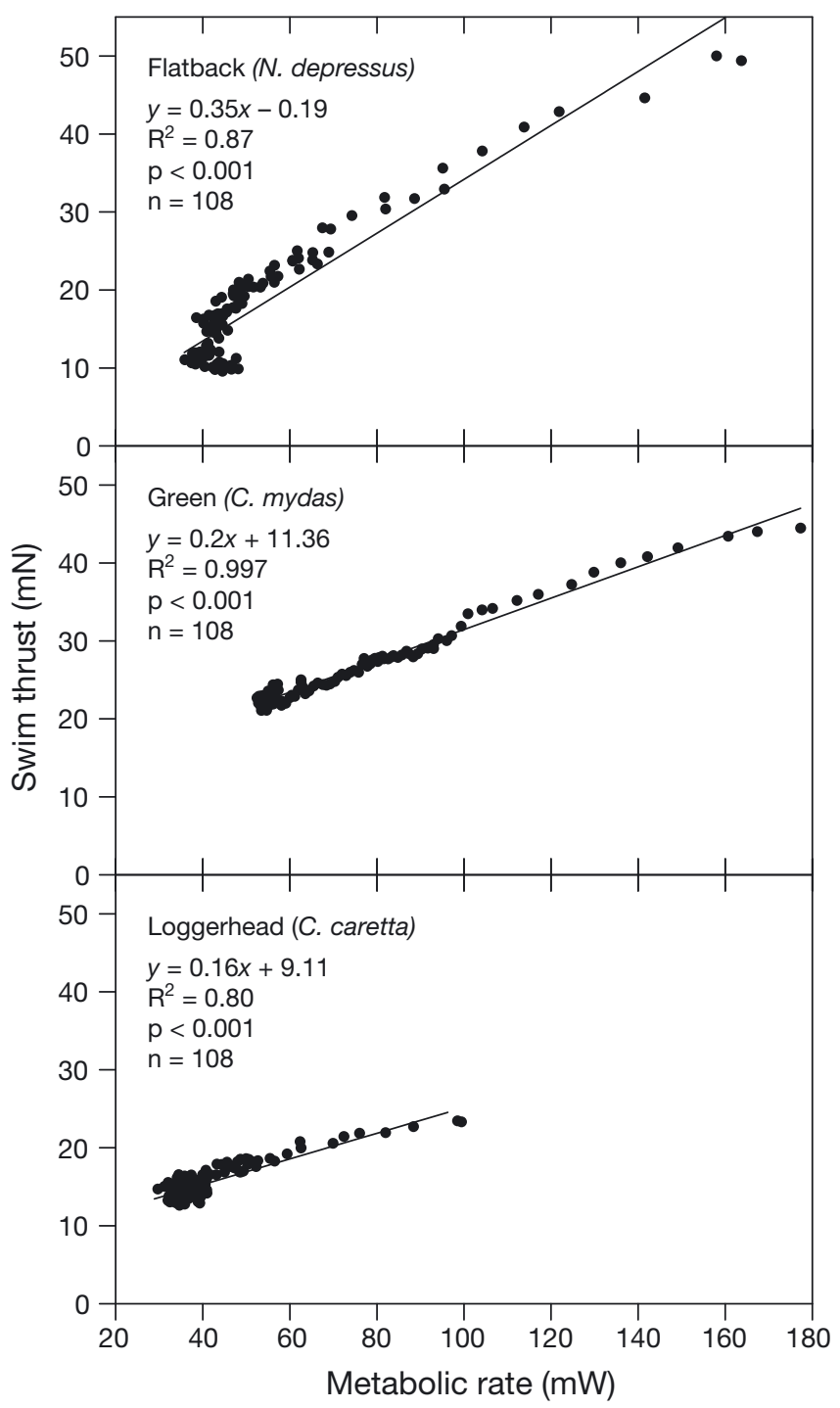

Fig. 2. Natator depressus, Caretta caretta and Chelonia mydas. Linear regression between metabolic rate and swim thrust in flatback and loggerhead turtle hatchlings from Mon Repos rookery and green turtle hatchlings from Heron Island rookery. Each point corresponds to the mean of each $10 \mathrm{~min}$ interval, estimated for each parameter, throughout the $18 \mathrm{~h}$ of swimming among loggerhead, flatback and green turtle hatchlings. Significant interspecies differences were found in hatchlings mass $\left(F_{2,30}=222.66\right.$, $\left.\mathrm{p}<0.001\right)$, swim thrust during the first $10 \mathrm{~min}$ of swimming $\left(F_{2,29}=43.75, \mathrm{p}<0.001\right)$, swim thrust during the last $10 \mathrm{~min}$ of the $18 \mathrm{~h}$ swimming trial $\left(F_{2,30}=22.94, \mathrm{p}<\right.$ 0.001 ) and metabolic rate during the first $10 \mathrm{~min}$ of swimming $\left(F_{2,29}=22.08, \mathrm{p}<0.001\right)$ but not in the metabolic rate during the last $10 \mathrm{~min}$ of the $18 \mathrm{~h}$ swimming trial $\left(F_{2,30}=3.04, \mathrm{p}=0.063\right.$; Table 1$)$. For all species, swim thrust and metabolic rate were greater during the first $10 \mathrm{~min}$ of swimming compared to the last $10 \mathrm{~min}$ ( $\mathrm{p}<0.001$ in all cases). Flatback turtle hatchlings had greater mass than green turtle hatchlings, which were greater than loggerhead turtle hatchlings (Table 1). Flatback and green turtle hatchlings produced greater swim thrust than loggerhead turtles during the first $10 \mathrm{~min}$ of swimming. After $18 \mathrm{~h}$ of swimming, green turtle hatchlings produced the greatest swim thrust, followed by loggerhead hatchlings, which had swim thrusts greater than flatback hatchlings (Table 1). Metabolic rate during the first $10 \mathrm{~min}$ of swimming was greatest in green turtles, intermediate in flatback turtles and lowest in loggerhead turtles, but was similar in all 3 species during the last $10 \mathrm{~min}$ of the 18 h swimming trial (Table 1).

Although the general pattern of declines in swimming thrust and metabolic rate was similar in all 3 species (initial rapid decline, a period of slower decline and then a period of no decline), there were subtle interspecies differences, with flatback hatchlings being notably different from green and loggerhead hatchlings. All 3 species experienced the steepest decline in metabolic rate within the first $2 \mathrm{~h}$ of swimming (Fig. 1A), with flatback hatchlings experiencing the greatest decrease (61\% decline), followed by loggerhead hatchlings (55\%) and green hatchlings (44\%). Green turtle hatchlings had the greatest metabolic rate throughout the entire monitored period. The period of steady decline was from 2 to $8 \mathrm{~h}$ in flatback and loggerhead hatchlings, but extended to $12 \mathrm{~h}$ in green hatchlings (Fig. 1A). Similarly, all 3 species experienced the greatest decline in swim thrust within the first $2 \mathrm{~h}$ of entering the water, with flatbacks experiencing the greatest decline (40\%), and green and loggerhead hatchling swim thrust falling by $22 \%$ (Fig. 1B). Swim thrust of flatback hatchlings continued to decline for the remaining $16 \mathrm{~h}$, while swim thrust of both green and loggerhead hatchlings declined slowly until $12 \mathrm{~h}$, but then remained constant for the last $6 \mathrm{~h}$ of the $18 \mathrm{~h}$ swimming trial (Fig. 1B). 
Table 1. Natator depressus, Chelonia mydas and Caretta caretta. Means \pm SE for hatchling variables and post hoc Fisher LSD multiple comparisons test between flatback (F), green (G) and loggerhead (L) hatchlings. Data for green turtle hatchlings taken from Booth (2009). SCL: shell carapace length, SCW: shell carapace width, BT: body thickness, RFFTL: right front flipper total length

\begin{tabular}{|c|c|c|c|c|}
\hline Variable & Flatback $(\mathrm{n}=13)$ & Green $(\mathrm{n}=5)$ & Loggerhead $(\mathrm{n}=15)$ & Post hoc comparison \\
\hline Mass (g) & $41.44 \pm 0.77$ & $25.62 \pm 0.76$ & $19.59 \pm 0.71$ & $\mathrm{~F}>\mathrm{G}>\mathrm{L}$ \\
\hline $\mathrm{SCL}(\mathrm{cm})$ & $5.99 \pm 0.04$ & Not reported & $4.32 \pm 0.03$ & $\mathrm{~F}>\mathrm{L}$ \\
\hline $\mathrm{SCW}(\mathrm{cm})$ & $4.78 \pm 0.07$ & Not reported & $3.50 \pm 0.07$ & $\mathrm{~F}>\mathrm{L}$ \\
\hline $\mathrm{BT}(\mathrm{cm})$ & $1.99 \pm 0.04$ & Not reported & $1.63 \pm 0.04$ & $\mathrm{~F}>\mathrm{L}$ \\
\hline RFFTL (cm) & $4.76 \pm 0.05$ & Not reported & $4.03 \pm 0.04$ & $\mathrm{~F}>\mathrm{L}$ \\
\hline $\begin{array}{l}\text { Swim thrust during first } \\
10 \text { min of swimming }(\mathrm{mN})\end{array}$ & $49.72 \pm 2.2$ & $44.40 \pm 3.4$ & $23.44 \pm 2.0$ & $\mathrm{~F}=\mathrm{G}>\mathrm{L}$ \\
\hline $\begin{array}{l}\text { Swim thrust during last } \\
10 \text { min of swimming }(\mathrm{mN})\end{array}$ & $9.24 \pm 1.1$ & $23.44 \pm 1.92$ & $14.06 \pm 1.05$ & $\mathrm{G}>\mathrm{L}>\mathrm{F}$ \\
\hline $\begin{array}{l}\text { Metabolic rate during the } \\
\text { first } 10 \text { min of swimming }(\mathrm{mW})\end{array}$ & $154.0 \pm 8.7$ & $186.9 \pm 13.5$ & $97.6 \pm 7.8$ & $\mathrm{G}>\mathrm{F}>\mathrm{L}$ \\
\hline $\begin{array}{l}\text { Metabolic rate during the } \\
\text { last } 10 \text { min of swimming }(\mathrm{mW})\end{array}$ & $46.3 \pm 4.4$ & $54.5 \pm 7.1$ & $36.4 \pm 4.1$ & $\mathrm{~F}=\mathrm{G}=\mathrm{L}$ \\
\hline
\end{tabular}

\section{DISCUSSION}

Morphological measurements of mass and size of loggerhead, flatback and green hatchlings reported here are similar to those previously reported in the east Australian populations of these species (Limpus $2008 \mathrm{a}, \mathrm{b}, \mathrm{c})$. The method used to assess the swim thrust in our study has been used before and is a good estimate of the free-swimming behaviour in hatchlings (Wyneken 1997). The general pattern of a decrease in swim thrust and metabolic rate as swimming time proceeded, with the decreases being greatest during the first $2 \mathrm{~h}$ of swimming, was common to all 3 species examined. However, there were subtle species-specific differences. These differences can be related to the hypothesis posed in the 'Introduction' that flatback hatchlings have a different swimming strategy than green and loggerhead turtles.

Hatchling size might influence swimming thrust as evidenced by the higher swim thrust of the larger flatback hatchlings during the first $30 \mathrm{~min}$ of swimming (Fig. 1B, Table 1). However, although flatback hatchlings have the potential to produce greater swim thrust than green and loggerhead turtles, as swimming time increased, their swim thrust decreased at a faster rate than green and loggerhead turtles so that after $30 \mathrm{~min}$ of swimming, their swim thrust was less than green turtle hatchlings, and it fell below that of loggerhead turtles after $11 \mathrm{~h}$ of swimming (Fig. 1B). Green turtle hatchlings produced the highest swim thrust from 30 min onwards (Fig. 1B) and also had the highest rate of oxygen consumption (Fig. 1A), which suggests that they are more vigorous swimmers than loggerhead and flatback hatchlings during this period. In our crude assessment of swimming efficiency in terms of the rate of thrust production per power consumed (Fig. 1C), the temporal variation was different for each species, and this variation might be related to swimming behaviour. All species showed an initial increase in swimming efficiency during the first $6 \mathrm{~h}$ of swimming (Fig. 1C), and this is probably due to a combination of learning to stroke more efficiently and a decrease in the powerstroke rate during this time (Booth 2009). However, in flatback hatchlings, swimming efficiency began declining slowly after the peak at $6 \mathrm{~h}$ and decreased sharply from $10 \mathrm{~h}$ onward, whereas in loggerhead turtles, the peak occurred at $8 \mathrm{~h}$ before decreasing steadily (Fig. 1C). A possible explanation for these apparent decreases in swim efficiently may be that the proportion of time spent powerstroking, dogpaddling and resting changes during these periods. Greater thrust is produced during powerstroking than during dogpaddling, and no thrust is produced during rest (Burgess et al. 2006, Booth 2009). If after $6 \mathrm{~h}$ of swimming, the proportion of time spent resting increases, there will be an apparent decrease in swimming efficiency because no thrust is produced during these times, but metabolic rate does not drop to 0 because metabolic rate needs to be maintained at a resting rate above 0 in order to maintain body tissues during these periods.

Flatback hatchlings did not swim as vigorously as green and loggerhead turtle hatchlings, suggesting that flatback hatchlings might not use anaerobic metabolism as extensively as green and loggerhead hatchlings, particularly during the first hour of swim- 
ming. Previous studies have shown that during high physical activity, sea turtles use both aerobic and anaerobic metabolism (Dial 1987) and that lactate accumulation, a by-product of anaerobic metabolism, varies among species (Milton \& Lutz 2003). Green turtle hatchlings maintain high blood lactate levels throughout their first hours of swimming (Baldwin et al. 1989, Milton \& Lutz 2003, Hamann et al. 2007), and loggerhead turtle hatchlings also maintain elevated blood lactate concentrations, but not as high as green turtle hatchlings (Baldwin et al. 1989, Milton \& Lutz 2003). Leatherback hatchlings have even lower blood lactate concentrations at this time, suggesting they use anaerobic metabolism less extensively during the frenzy swimming phase (Milton \& Lutz 2003) in the same manner that we suspect happens in flatback hatchlings.

The lower overall swim thrust production of flatback hatchlings compared to green and loggerhead hatchlings after $12 \mathrm{~h}$ of swimming appears to contradict the finding that flatback hatchling swimming activity (as measured by the proportion of time swimming or not swimming) remains high throughout the first $4 \mathrm{~d}$ of swimming after entering the water, although it decreases remarkably after the first day in other sea turtle species (Salmon et al. 2009). Indeed, Salmon et al. (2009) questioned how, from an energetic point of view, flatback hatchlings could swim continuously for $4 \mathrm{~d}$ without showing any signs of interest in feeding. Our study indicates that this is possible because, although flatback hatchlings appear to swim continuously (Salmon et al. 2009), they put relative little effort into swimming during this time, i.e. they swim less vigorously than green and loggerhead turtle hatchlings during the swimming frenzy. A lower swim effort is consistent with current ideas on dispersal movement of flatback hatchlings. Flatback turtles are mostly endemic to the Australian continental shelf (Walker \& Parmenter 1990), with a restricted geographical distribution, although they have been reported outside the Australian continental shelf in the coastal waters of Kei (eastern Indonesia; Limpus 2008b). It has long been speculated that species that lack an oceanic phase in their life cycle, such as the flatback (Limpus 2008b), should have an abbreviated frenzy swimming phase (Wyneken 1997). If flatback turtle hatchlings do not swim long distances to meet offshore oceanic currents, there is no need for a vigorous swimming frenzy (Wyneken 1997). Although flatback hatchlings generally use a low thrust swim, when motivated they can reach higher speeds than green hatchlings, with the fastest sea turtle hatchling swimming speeds recorded to date coming from flatback hatchlings (Salmon et al. 2010).

The 'predation risk' hypothesis proposes that nearshore predation pressure influences the swimming strategies used by sea turtle hatchlings while swimming offshore (Chung et al. 2009a,b, Salmon et al. 2009). In species such as green, loggerhead and leatherback turtles, hatchlings are hypothesized to engage in an energetically demanding swimming frenzy immediately after entering the sea for the first time in order to reduce the time spent in shallow waters where there is a high density of predators (Gyuris 1994, 2000, Booth et al. 2004, Whelan \& Wyneken 2007, Salmon et al. 2009). Hawksbill Eretmochelys imbricata hatchlings, however, show a completely different dispersal strategy, remaining inactive on the water surface drifting passively in currents that take them away from the shore during the first few days after entering the water (Chung et al. 2009a,b). This strategy is believed to use mimicry (resembling dead leaves and other flotsam surfacing on the water) and crypsis (resembling the surrounding background, such as algal mats) to avoid attracting predator attention (Chung et al. 2009a,b).

Recent studies report that differences in swimming vigour also extend to populations within a species. Wyneken et al. (2008) reported that loggerhead turtle hatchlings derived from the southwestern coast of Florida (USA) are more active swimmers than the hatchlings from the southeastern coast of Florida, despite being part of the same genetic population. Likewise, Chung et al. (2009a) reported a 2 d swimming frenzy in green turtle hatchlings from Malaysia in contrast to the $1 \mathrm{~d}$ swimming frenzy of green turtle hatchlings from Florida. Both findings have been interpreted as adaptations to different ecological demands of the post-hatching environment. In the first case, the southwestern Florida population of hatchling loggerhead turtles is hypothesized to comprise more active swimmers because they must travel farther to offshore dispersing currents than the southeastern population (Wyneken et al. 2008). In the second case, it was hypothesized that higher predation pressure in waters off Malaysia results in green turtle hatchlings having a longer frenzy swim period compared to the Florida population (Chung et al. 2009a).

Hence, both inter- and intraspecific differences in hatchling swimming behaviour might be explained by the interaction between different ecological conditions such as near-shore predation rates, distance to offshore oceanic dispersing currents (Wyneken et al. 2008, Chung et al. 2009a,b, Salmon et al. 2009) and anti-predator tactics of hatchlings. Predation rate 
of sea turtle hatchlings swimming off their natal beaches varies widely and is dependent on the substrate of fringing nesting beaches (Salmon et al. 2009). Beaches in which the offshore substrate is primarily sand with turbid waters have much lower predation rates than beaches that are surrounded by coral reefs and clear water because of differences in the density of predator fish in these habitats (Salmon et al. 2009). Differences in predator avoidance behaviour may also influence swimming tactics. For example, green turtle hatchlings are reported to show no evasive manoeuvres when approached by a predator, their only predator defence being swimming as fast as possible to decrease the time they are exposed to high near-shore predator density (Gyuris 1994). In contrast, flatback hatchlings appear to be able to detect predators and take avoidance action (Salmon et al. 2009), and thus may not need to swim as vigorously. If the hypothesis that sea turtle hatchling swim thrust within the first few hours of entering the water is related to the predator density in the near-shore waters of nesting beaches is true, this may explain why we found green turtle hatchlings to be more vigorous swimmers compared to loggerhead and flatback turtle hatchlings. Mon Repos beach, where our loggerhead and flatback turtles were sampled, has a low predator density, sandy substrate and turbid water, whereas Heron Island, where our green turtles were sampled, has a coral reef substrate with clear water. To test this hypothesis, the swim thrust performance of loggerhead hatchlings that emerge from nests laid on coral cays of the south eastern Australian population would have to be measured and compared to that of the hatchlings from Mon Repos reported here. The expectations would be a more vigorous swim frenzy in loggerhead hatchlings from coral cays than those we sampled at the Mon Repos rookery. A few green turtles nest at the Mon Repos rookery, so it would also be predicted that green turtle hatchlings from Mon Repos would have a less vigorous swimming frenzy than those from Heron Island. This hypothesis cannot be tested in flatback turtles because no coral cay rookery is known for this species (Limpus 2008b).

All 3 species of sea turtle hatchlings that we examined produced their highest swim thrust during the first $2 \mathrm{~h}$ of swimming, a strategy designed to move the hatchlings quickly out of the shallow predatorrich near-shore waters (Bustard 1972, Gyuris 1994, 2000). However, subtle interspecies differences in swimming thrust were detected after the first $2 \mathrm{~h}$. These differences in swimming behaviour are probably a result of a complex interaction between near- shore predator density, the distance that must be swum to reach offshore oceanic disbursing currents and hatchling anti-predator tactics.

Acknowledgements. This research conforms with Australian Animal Welfare laws and was approved by a University of Queensland Animal Ethics Committee (approval No. SBS/ 481/09). We thank the Mon Repos Conservation Park staff and volunteers and the DERM Turtle Conservation Volunteers for the help provided during the field work.

\section{LITERATURE CITED}

Baldwin J, Gyuris E, Mortimer K, Patak A (1989) Anaerobic metabolism during dispersal of green and loggerhead turtle hatchlings. Comp Biochem Physiol A Physiol 94: 663-665

Bartholomew GA, Vleck D, Vleck C (1981) Instantaneous measurements of oxygen consumption during pre-flight warm-up and post-flight cooling in sphingid and saturniid moths. J Exp Biol 90:17-32

> Bennett JM, Taplin LE, Grigg GC (1986) Sea water drinking as a homeostatic response to dehydration in hatchling loggerhead turtles Caretta caretta. Comp Biochem Physiol A Physiol 83:507-513

Booth DT (2009) Swimming for your life: locomotor effort and oxygen consumption during the green turtle (Chelonia mydas) hatchling frenzy. J Exp Biol 212:50-55

Booth DT, Burguess E, McCosker J, Lanyon JM (2004) The influence of incubation temperature on post-hatching fitness characteristics of turtles. Int Congr Ser 1275: 226-233

Burgess EA, Both DT, Lanyon JM (2006) Swimming performance of hatchling green turtles is affected by incubation temperature. Coral Reefs 25:341-349

Bustard R (1972) Sea turtles: natural history and conservation. Collins, London-Sydney

Chung FC, Pilcher NJ, Salmon M, Wyneken J (2009a) Offshore migratory activity of hawksbill turtle (Eretmochelys imbricata) hatchlings. I. Quantitative analysis of activity, with comparison to green turtles (Chelonia mydas). Chelonian Conserv Biol 8:28-34

Chung FC, Pilcher NJ, Salmon M, Wyneken J (2009b) Offshore migratory activity of hawksbill turtle (Eretmochelys imbricata) hatchlings. II. Swimming gaits, swimming speed, and morphological comparisons. Chelonian Conserv Biol 8:35-42

Dial BE (1987) Energetics and performance during nest emergence and the hatchling frenzy in loggerhead sea turtles (Caretta caretta). Herpetologica 43:307-315

Gyuris E (1994) The rate of predation by fishes on hatchlings of green turtle. Coral Reefs 13:137-144

Gyuris E (2000) The relationship between body size and predation rates on hatchlings of the green turtle (Chelonia mydas): Is bigger better? In: Pilcher N, Ismail M (eds) Sea turtles of the Indo-Pacific: research, management and conservation. Academic Press, New York, NY, p 143-147

Hamann M, Jessop TS, Schäuble CS (2007) Fuel use and corticosterone dynamics in hatchling green sea turtles (Chelonia mydas) during natal dispersal. J Exp Mar Biol Ecol 353:13-21 
Hays GC, Åkesson S, Broderick AC, Glen F and others (2001) The diving behaviour of green turtles undertaking oceanic migration to and from Ascension Island: dive duration, dive profiles and depth distribution. J Exp Biol 204:4093-4098

Hays GC, Fossette S, Katselidis KA, Mariani P, Schofield G (2010) Ontogenetic development of migration: Lagrangian drift trajectories suggest a new paradigm for sea turtles. J R Soc Interface 7:1319-1327

Ischer T, Ireland K, Booth DT (2009) Locomotion performance of green turtle hatchlings from Heron Island Rookery, Great Barrier Reef. Mar Biol 156:1399-1409

Jones T, Reina R, Lutz P (2003) A comparison of the ontogeny of oxygen consumption in leatherback, Dermochelys coriacea, and olive ridley, Lepydochelys olivacea, sea turtle hatchlings - different strokes for different life styles. In: Seminoff JA (comp) Proc 22nd Annu Symp Sea Turtle Biol Conserv. NOAA Tech Memo NMFS-SEFSC503. NMFS Miami Laboratory Sea Turtle Program, Miami, FL, p 191-192

Jones TT, Reina R, Darveau C, Lutz PL (2007) Ontogeny of energetics in leatherback (Dermochelys coriacea) and olive ridley (Lepidochelys olivacea) sea turtle hatchlings. Comp Biochem Physiol A Mol Integr Physiol 147: 313-322

Koteja P (1996) Measuring energy metabolism with open flow respirometric systems: Which design to choose? Funct Ecol 10:675-677

Lighton JRB (2008) Flow-through respirometry using incurrent flow measurement. In: Lighton JRB (ed) Measuring metabolic rates, a manual for scientists. Oxford University Press, Oxford, p 105-123

Lighton JRB, Bartholomew GA, Feener DH (1987) Energetics of locomotion and load carriage and a model of energy cost of foraging in the leaf-cutting ant Atta colombica. Physiol Zool 60:54-57

Limpus CJ (2008a) A biological review of Australian marine turtles. 1. Loggerhead turtle Caretta caretta (Linnaeus). Freshwater and Marine Sciences Unit, Environmental Sciences Division, Environmental Protection Agency, Queensland

Limpus CJ (2008b) A biological review of Australian marine turtles. 5. Flatback turtle Natator depressus (Garman). Freshwater and Marine Sciences Unit, Environmental Sciences Division, Environmental Protection Agency, Queensland

Limpus CJ (2008c) A biological review of the Australian marine turtle species. 2. Green turtle, Chelonia mydas (Linnaeus). Freshwater and Marine Sciences Unit, Environmental Sciences Division, Environmental Protection Agency, Queensland

Limpus CJ, Limpus DJ (2003) Loggerhead turtles in the equatorial and southern Pacific Ocean: a species in decline. In: Bolten AB, Witherington BE (ed) Loggerhead sea turtles. Smithsonian Institution, Washington, DC, p 199-209

Limpus CJ, Fleay A, Baker V (1984) The flatback turtle, Chelonia depressa, in Queensland: reproductive periodicity, philopatry and recruitment. Aust Wildl Res 11: 579-587

Miller JD (1997) Reproduction in sea turtles. In: Lutz PL,
Musick JA (eds) The biology of sea turtles. CRC Press, Boca Raton, FL, p 51-81

Milton SL, Lutz PL (2003) Physiological and genetic responses to environmental stress. In: Lutz PL, Musick JA, Wyneken J (eds) The biology of sea turtles, Vol II. CRC Press, Boca Raton, FL, p 163-197

Pfaller JB, Limpus CJ, Bjorndal KA (2008) Nest-site selection in individual loggerheadsturtles and consequences for doomed-egg relocation. Conserv Biol 23: 72-80

Pritchard PCH, Mortimer JA (1999) Taxonomy, external morphology and species identification. In: Eckert KL, Bjorndal KA, Abreu-Grobois FA, Donnelly M (eds) Research and management techniques for the conservation of sea turtles. IUCN/SSC Marine Turtle Specialist Group Publication No. 4. PA, SSC/IUCN Marine Turtle Specialist Group, Washington, DC, p 21-40

Putman NF, Bane JM, Lohman KJ (2010) Sea turtle nesting distributions and oceanographic constraints on hatchling migration. Proc R Soc Lond B Biol Sci 277 no. 1700: 3631-3637

Salmon M, Wyneken J (1987) Orientation and swimming behaviour of hatchling loggerhead turtles Caretta caretta L. during their offshore migration. J Exp Mar Biol Ecol 109:137-153

Salmon M, Hamann M, Wyneken J, Schauble C (2009) Early swimming activity of the hatchling flatback sea turtles Natator depressus: a test of the 'predation risk' hypothesis. Endang Species Res 9:41-47

Salmon M, Hamann M, Wyneken J (2010) The development of early diving behavior by juvenile flatback sea turtles (Natator depressus). Chelonian Conserv Biol 9:8-17

Schmidt-Nielsen K (1997) Animal physiology: adaptation and environment. Cambridge University Press, Cambridge

Walker TA, Parmenter CJ (1990) Absence of a pelagic phase in the life cycle of flatback turtle, Natator depressa (Garman). J Biogeog 17: 275-278

> Whelan CL, Wyneken J (2007) Estimating predation levels and site-specific survival of hatchling loggerhead sea turtles (Caretta caretta) from South Florida beaches. Copeia 2007:745-754

Witherington BE, Salmon M (1992) Predation on loggerhead turtle hatchlings after entering the sea. J Herpetol 26: 226-228

Wyneken J (1991) Comparisons of oxygen utilization by hatchling loggerhead, greens and leatherbacks during the swimming frenzy: sprinting vs. marathon strategies revisited. In: Salmon M, Wyneken J (eds) Proc 11th Ann Workshop on Sea Turtle Biology and Conservation. NOAA Tech Memo NMFS-SEFSC-302, p 131-132

Wyneken J (1997) Sea turtle locomotion: mechanisms, behavior and energetics. In: Lutz PL, Musick JA (eds) The biology of sea turtles. CRC Press, Boca Raton, FL, p 165-198

> Wyneken J, Salmon M (1992) Frenzy and postfrenzy swimming activity in loggerhead, green and leatherback hatchlings sea turtles. Copeia 1992:478-484

> Wyneken J, Madrak SV, Salmon M, Foote J (2008) Migratory activity by hatchling loggerhead sea turtles (Caretta caretta L.): evidence for divergence between nesting groups. Mar Biol 156:171-178

Submitted: May 5, 2011; Accepted: January 6, 2012 Proofs received from author(s): March 11, 2012 